\title{
Opinion of Arab Physicians on Factors Enhancing or Disabling their Publishing Biomedical Research
}

\author{
Milad El-Segaier, $\mathrm{MD}, \mathrm{PhD}^{1^{*}}$, Salma B Galal, $\mathrm{MD}, \mathrm{PhD}^{2 *}$, Ahmad Bahnassy, MSc, MSPH, $\mathrm{PhD}^{3}$ \\ Amin Bredan $\mathrm{PhD}^{4}$, Mohammed Omar Galal, $\mathrm{MD}, \mathrm{PhD}, \mathrm{MBA}^{5}$ \\ ${ }^{I}$ Department of Paediatric Cardiology, KingFahad Medical City, KSHC, Riyadh, Saudi Arabia \\ ${ }^{2}$ Department of Community and Industrial Medicine, Faculty of Medicine (Girls), Al Azhar University, Cairo, \\ Egypt \\ ${ }^{3}$ Department of Biomedical Statistics, Faculty of Medicine, KFMC, Riyadh, Saudi Arabia \\ ${ }^{4}$ Formerly with VIB and Ghent University, Independent scholar, Belgium \\ ${ }^{5}$ King Faisal Specialist Hospital \& RC, Jeddah, Saudi Arabia
}

\begin{abstract}
*Corresponding Author: Milad El-Segaier, MD, PhD, Salma B Galal, MD, PhD, Department of Paediatric Cardiology, King Fahad Medical City, KSHC, Riyadh, Saudi Arabia, Department of Community and Industrial Medicine, Faculty of Medicine (Girls), Al Azhar University, Cairo, Egypt Email:mail4milad@gmail.com
\end{abstract}

\begin{abstract}
Possible factors for limitation of publication of physicians and their improvement suggestions were investigated. This exploratory study on the opinion of 115 physicians compares those publishing and not publishing attending Cardiology Conference of Arab countries in Riyadh, Saudi Arabia 2014. All physicians (180) were given the questionnaire, $68.3 \%$ responded. The self-administered questionnaire included beside characteristics of the physician, country of study, attendance of research method course, research and publication activity. Personal factors, institutional /policy factors and suggestions for improvement were explored.
\end{abstract}

Forty seven percent (46.9\%) of physicians published biomedical research. Older physicians publish more biomedical research than younger $(p=0.01)$, male more than female physicians $(p=0.047)$. Those who attended research methods course publish significantly more than the others $(p=0.01)$. Almost half of all physicians mentioned lack of time as impeding factor. Institutional / policy factors such as "decision makers do not support research", "no time allocation for research at work", or "no mentoring of research" are limiting factors for publication. The majority of physicians suggest the reform of medical education.

Keywords: Scientific publishing - research - Arab countries - physicians

\section{INTRODUCTION}

The scientific activities of universities and research centres are assessed by the quantity and quality of publications [1]. The evaluation of biomedical publications from Arab countries has shown that its quantity and quality lag far behind the rest of the world[2] although it increased in the last decade such as in Saudi Arabia [3]. The contribution of the Arab countries to PubMed is only $0.6 \%$. Saudi Arabia and Egypt publish almost half of them [4]. According to UNESCO 2005, USA and Europe share is two third in scientific publications while all developing countries together make $11 \%$ [5]. Only very few publications addressed this issue and tried to understand the reasons related to it.
The published studies assessing biomedical research output of Arab countries have been mainly quantitative $[6,7]$. The cause behind this poor performance is unclear. The best populations who can explain the possible reasons for the deficient deliveries of biomedical publication are the health care professionals themselves.

Saudi Arabia is one of the largest Middle Eastern Countries attracting many international health care professionals who have been educated and trained abroad. This makes them along with the Saudi colleagues, an adequate sample to give an appropriate answer to our questions in regard to the causes behind this deficiency. Additionally, they may have an opinion as to how to improve this situation. 
This study attempts to explore the possible factors for the production of biomedical publication. Furthermore, it also tries to come up with some possible improvement to enhance publication.

\section{Methods AND SubJECTS}

This research is an exploratory survey of physicians attending 4-days Cardiology Conference of Arab countries in Saudi Arabia 2014. From 180 questionnaires distributed to the physicians, 123 were returned and 8 were excluded for being incomplete. Attendees of this meeting included cardiac surgeons, adult and paediatric cardiologists, internal medicine physicians, general paediatricians, clinical pharmacists, intensive care physicians, and anaesthetists.

Participating physicians were assured that the information they provide is confidential and only used for scientific research. The questionnaire was anonymous. The participants were given the option to refuse to fill the questionnaire. Returning the filled selfadministered questionnaire is considered their consent.

A questionnaire with a total of three parts was designed.

The first part included the demographic data, country of undergraduate medical education, the country of postgraduate medical training, the highest educational degree reached, their clinical speciality and its duration, and the nature of their current position. Responders who have more than one job category were asked to rank them according degree of involvement. Additionally, it included whether the participant was trained and involved in any scientific research or publications.

The second part focused on questions about their opinion for the reasons behind such low production of research in Arab Countries. The responder was given 13 questions which focused on three main options:

- the reason is due to poor undergraduate education and curriculum,

- the reason is due to the institute in regards to lack of protected time, unavailability of databases or registries, lack of supervision and lack of economic support,

- the reason is personal in regard to unwillingness or other personal commitments,
- a general reason in regard to decision maker do not consider research importance.

The responders were allowed to select more than one reason.

The third part addresses the opinion of the participants about their ideas how to best improve this situation. The responder was given six questions which are mainly focused on improvement of the institutional factors which are pointed in the second part. At the end of both second and third part the responders had the chance to describe in their own words the reasons behind low biomedical publication productivity and the methods to improve that.

The Institutional Review Board (IRB) at King Fahd Medical City (KFMC) approved this research.

\section{DATA PROCESSING}

The questionnaire was tested by Cronbach alpha test to evaluate the reliability of its answers. For this reason it was delivered initially to a pilot group of 20 physicians. The result of this test showed an alpha value of 0.7 , which indicated an acceptable reliability.

SPSS version 17 was used for the statistical analysis. Publishing physicians and those not publishing were compared. The Chi-square and t-test were used to determine the statistical significance of association between variables. In addition logistic regression was used to predict the most important factors for publishing / not publishing. The $\mathrm{p}$-value $\leq 0.05$ was considered significant.

\section{AIM OF THE STUDY}

The aim of this study was to explore some factors enabling/ disabling production of biomedical publication of physicians and their suggestions to improve publication.

\section{RESULTS}

Response rate was 68\% (123/180). Further incomplete responses $(\mathrm{n}=8)$ were excluded. A total of 115 responses (25\% females, $75 \%$ males) were analysed. The current job of physicians shows that over $80 \%$ are involved in patient care, $10 \%$ are researchers, $5 \%$ in education, and $5 \%$ in administration.

A total of $46.9 \%$ had publications, while $53.1 \%$ did neverpublish. $60 \%$ were doing research and $40 \%$ not.

Table 1compares publishing and not publishing physicians. It shows that there are significantly 
more male physicians publishing researches than female physicians. Two third of the interviewed physicians are pediatricians (39\%) or internists $(36 \%)$. Publishing physicians are significantly older than not publishing physicians.
The undergraduate education was $74 \%$ in Arab countries, $9.6 \%$ in Africa, 8.7\% in Pakistan / India and6 \% in Europe or North America.

The highest degree of education was 19\% Arab Board, $20 \%$ PhD, $13 \%$ had Master Degree and the rest had baccalaureate or local degree.

Table1. Characteristics of Publishing and not Publishing Physicians

\begin{tabular}{|c|c|c|c|c|}
\hline Variable & $\begin{array}{l}\text { Publishing } \\
\text { physicians } \\
\text { N=54 }(\%)\end{array}$ & $\begin{array}{c}\text { Not publishing } \\
\text { physicians } \\
\mathrm{N}=61(\%)\end{array}$ & $\begin{array}{c}\text { Total } \\
\mathbf{N}=115 \\
(\%)\end{array}$ & $\begin{array}{c}\text { Significance test } \\
\text { p value }\end{array}$ \\
\hline $\begin{array}{l}\text { Gender } \\
\text { Female } \\
\text { Male }\end{array}$ & $\begin{array}{c}9(16.7) \\
45(83.3)\end{array}$ & $\begin{array}{cc}20 & (32.8) \\
4 & (67.2)\end{array}$ & $\begin{array}{l}(25.2) \\
(74.8)\end{array}$ & $\begin{array}{c}\text { Chi-sq }=3.94 \\
\mathrm{P}=0.047^{*}\end{array}$ \\
\hline $\begin{array}{l}\text { Country of } \\
\text { undergraduate study } \\
\text { Middle East Arab } \\
\text { Countries } \\
\text { North America } \\
\text { West Europe } \\
\text { India / Pakistan } \\
\text { Africa } \\
\text { East Europe } \\
\text { Others }\end{array}$ & $\begin{array}{cc}42 & (77.8) \\
1 & (1.9) \\
2 & (3.7) \\
5 & (9.3) \\
2 & (3.7) \\
1 & (1.9) \\
1 & (1.9)\end{array}$ & $\begin{array}{cc}43 & (70.3) \\
& \\
1 & (1.6) \\
1 & (1.6) \\
5 & (8.3) \\
9 & (14.8) \\
1 & (1.6) \\
1 & (1.6)\end{array}$ & $\begin{array}{l}(73.9) \\
(1.7) \\
(2.6) \\
(8.7) \\
(9.6) \\
(1.7) \\
(1.7)\end{array}$ & $\begin{array}{c}\text { Chi-sq }=6.4 \\
P=0.5\end{array}$ \\
\hline $\begin{array}{l}\text { Medical specialization } \\
\text { Pediatrics } \\
\text { Internal medicine } \\
\text { Surgery } \\
\text { General practitioner } \\
\text { Others }\end{array}$ & $\begin{array}{c}24(44.4) \\
18(33.3) \\
5(9.2) \\
2(3.7) \\
5(9.2)\end{array}$ & $\begin{array}{c}21(34.4) \\
24(39.3) \\
5(8.2) \\
5(8.2) \\
6(9.8)\end{array}$ & $\begin{array}{l}(39.1 \\
(36.5 \\
(8.7) \\
(6.1) \\
(9.6)\end{array}$ & $\begin{array}{l}\text { Chi-sq=2 } \\
\qquad P=0.7\end{array}$ \\
\hline $\begin{array}{l}\text { Age (years) } \\
22- \\
30- \\
40- \\
50+\end{array}$ & $\begin{array}{c}8(14.8) \\
22(40.7) \\
16(29.6) \\
8(14.8)\end{array}$ & $\begin{array}{c}20(32.8) \\
22(36.1) \\
16(26.2) \\
3(4.9)\end{array}$ & $\begin{array}{l}(24.3) \\
(38.3) \\
(27.8) \\
(9.6)\end{array}$ & $\begin{array}{c}\text { Chi-sq }=7.0 \\
P=0.07\end{array}$ \\
\hline $\begin{array}{l}\text { Mean age } \pm \text { SD } \\
(22-69 \text { years })\end{array}$ & $41.0 \pm 9.8$ & $36.5 \pm 9.1$ & & $\begin{array}{c}\text { t-test }=2.57 \\
\mathrm{p}=0.01 *\end{array}$ \\
\hline $\begin{array}{l}\text { Mean duration since } \\
\text { graduation } \pm \text { SD } \\
(0-30 \text { years })\end{array}$ & $16.2 \pm 10.2$ & $11.7 \pm 8.9$ & & $\begin{array}{c}\mathrm{t} \text {-test }=2.5 \\
\mathrm{p}=0.01 *\end{array}$ \\
\hline
\end{tabular}

* significant

Table 2 demonstrates that $60.8 \%$ of physicians had postgraduate education in Arab countries, 9.5\% in USA, and $13.9 \%$ in Europe. Physicians with postgraduate studies in USA published more than others $(91.7 \%)$, followed by India/Pakistan (50\%), West Europe (46\%), Middle East Arab countries (40\%), East Europe and Africa $(33 \%)$.
Two third of physicians attended research method courses.Significantly more of those publishing $(77.8 \%)$ attended a research method course than those not publishing, and significantly more of them $(85.2 \%)$ are doing research at present.

Table2. Study, research course and present research of publishing and not publishing physicians

\begin{tabular}{|l|c|c|c|c|}
\hline \multicolumn{1}{|c|}{ Variable } & $\begin{array}{c}\text { Publishing } \\
\text { physicians } \\
\mathbf{N = 5 4}\end{array}$ & $\begin{array}{c}\text { Not publishing } \\
\text { physicians } \\
\mathbf{N = 6 1}\end{array}$ & $\begin{array}{c}\text { Total } \\
\mathbf{N = 1 1 5} \\
\mathbf{( 1 0 0 \% )}\end{array}$ & $\begin{array}{c}\text { Significance test } \\
\text { p value }\end{array}$ \\
\hline Country of post-graduate study & (row\%) & (row\%) & & Yates Chi- \\
Middle East Arab Countries & $28(40.0)$ & $42(60.0)$ & $(60.8)$ & sq=12.0 \\
North America & $\mathbf{1 1 ( 9 1 . 7 )}$ & $\mathbf{1}(\mathbf{8 . 3 )}$ & $(9.5)$ & $\mathrm{P}=0.06$ \\
West Europe & $6(46.1)$ & $7(53.9)$ & $(11.3)$ & \\
India / Pakistan & $3(50.0)$ & $3(50.0)$ & $(5.2)$ & \\
Africa & $2(33.3)$ & $4(66.6)$ & $(4.3)$ & \\
\hline
\end{tabular}




\begin{tabular}{|c|c|c|c|c|}
\hline $\begin{array}{l}\text { East Europe } \\
\text { Others }\end{array}$ & $\begin{array}{l}1(33.3) \\
3(60.0)\end{array}$ & $\begin{array}{ll}2 & (66.6) \\
2 & (40.0) \\
\end{array}$ & $\begin{array}{l}(2.6) \\
(4.3)\end{array}$ & \\
\hline & $\mathrm{N}(100 \%)$ & $\mathrm{N}(\mathbf{1 0 0 \%})$ & & \\
\hline $\begin{array}{l}\text { Limited research methodology at } \\
\text { university } \\
\text { Yes } \\
\text { No }\end{array}$ & $\begin{array}{ll}37 & (68.5) \\
17 & (31.5) \\
\end{array}$ & $\begin{array}{l}37(60.7) \\
24(39.3) \\
\end{array}$ & $\begin{array}{l}(64.3) \\
(35.7) \\
\end{array}$ & $\begin{array}{c}\text { Chi-sq }=0.7 \\
P=0.38\end{array}$ \\
\hline $\begin{array}{l}\text { Attended research courses } \\
\text { Yes } \\
\text { No }\end{array}$ & $\begin{array}{l}42(77.8) \\
12(22.2)\end{array}$ & $\begin{array}{l}34(55.7) \\
27(44.3)\end{array}$ & $\begin{array}{l}(66.1) \\
(33.9)\end{array}$ & $\begin{array}{c}\text { Chi-sq }=6.2 \\
P=0.01 *\end{array}$ \\
\hline $\begin{array}{l}\text { Doing research at present } \\
\text { Yes } \\
\text { No }\end{array}$ & $\begin{array}{c}46(85.2) \\
8(14.8)\end{array}$ & $\begin{array}{l}22(36.1) \\
39(63.9)\end{array}$ & $\begin{array}{l}(59.1) \\
(40.9)\end{array}$ & $\begin{array}{c}\text { Chi-sq }=28.6 \\
P=0.00 *\end{array}$ \\
\hline
\end{tabular}

*significant

Table 3 illustrates that there is no difference between publishing and not publishing physicians regarding the work environment except that significantly more of publishing physicians mentioned more 'lack of economic support to research' (64.8\%) than not publishing.
No difference were found between publishing and not publishing physicians regarding their personal limitations or commitments such as time, social, religious or political commitment. $48.7 \%$ of all physicians mentioned lack of time for research as limitation. Social, religious or political commitment were for 92- 97\% of physicians of no importance.

Table3. Work Environment Towards Research by Publishing and not Publishing Physicians

\begin{tabular}{|c|c|c|c|c|}
\hline Variable & $\begin{array}{l}\text { Publishing } \\
\text { physicians } \\
\mathrm{N}=54(\%)\end{array}$ & $\begin{array}{c}\text { Not publishing } \\
\text { physicians } \\
\mathrm{N}=61 \quad(\%)\end{array}$ & $\begin{array}{c}\text { Total } \\
\mathrm{N}=115 \\
(\mathbf{1 0 0 \%}) \\
\end{array}$ & $\begin{array}{c}\text { Significance } \\
\text { test } \\
\text { p value } \\
\end{array}$ \\
\hline $\begin{array}{l}\text { Institution doesn't give time for } \\
\text { research } \\
\text { Yes } \\
\text { No }\end{array}$ & $\begin{array}{ll}35 & (64.8) \\
19 & (35.2)\end{array}$ & $\begin{array}{ll}29 & (47.5) \\
32 & (52.5)\end{array}$ & $\begin{array}{l}(55.6) \\
(44.4)\end{array}$ & $\begin{array}{c}\text { Chi-sq }=3.46 \\
P=0.06\end{array}$ \\
\hline $\begin{array}{l}\text { Available database/ registry at work } \\
\text { Yes } \\
\text { No }\end{array}$ & $\begin{array}{l}26(48.4) \\
28(51.6)\end{array}$ & $\begin{array}{l}21(34.4) \\
40(65.6)\end{array}$ & $\begin{array}{l}(40.8) \\
(59.2)\end{array}$ & $\begin{array}{c}\text { Chi-sq }=2.2 \\
P=0.1\end{array}$ \\
\hline $\begin{array}{l}\text { Lack of mentoring of research } \\
\text { Yes } \\
\text { No }\end{array}$ & $\begin{array}{l}26(48.1) \\
28(51.9)\end{array}$ & $\begin{array}{l}23(37.2) \\
38(62.8)\end{array}$ & $\begin{array}{l}(42.6) \\
(57.4)\end{array}$ & $\begin{array}{c}\text { Chi-sq }=1.28 \\
P=0.26\end{array}$ \\
\hline $\begin{array}{l}\text { Lack of economic support to } \\
\text { research } \\
\text { Yes } \\
\text { No }\end{array}$ & $\begin{array}{l}35(64.8) \\
19(35.2)\end{array}$ & $\begin{array}{l}28(45.9) \\
33(54.1)\end{array}$ & $\begin{array}{l}(54.8) \\
(45.2)\end{array}$ & $\begin{array}{c}\text { Chi-sq }=4.1 \\
P=0.04^{*}\end{array}$ \\
\hline $\begin{array}{l}\text { Lack of reward / benefit from } \\
\text { research } \\
\text { Yes } \\
\text { No }\end{array}$ & $\begin{array}{l}22(40.9) \\
32(59.1)\end{array}$ & $\begin{array}{l}20(32.8) \\
41(67.2)\end{array}$ & $\begin{array}{l}(36.5) \\
(63.5)\end{array}$ & $\begin{array}{c}\text { Chi-sq }=0.78 \\
P=0.38\end{array}$ \\
\hline $\begin{array}{l}\text { Decision makers don't consider } \\
\text { research important } \\
\text { Yes } \\
\text { No } \\
\end{array}$ & $\begin{array}{l}17(31.5) \\
37(68.5) \\
\end{array}$ & $\begin{array}{r}16(26.2) \\
45(73.8) \\
\end{array}$ & $\begin{array}{l}(28.7) \\
(71.3)\end{array}$ & $\begin{array}{c}\text { Chi-sq }=0.38 \\
P=0.5\end{array}$ \\
\hline
\end{tabular}

*significant

Table 4 presents the suggestions regarding improvement of research. $75 \%$ of physicians asked for medical education reform. Economic support and encouragement of research are significantly more mentioned by publishing than not publishing physicians.

Table4. Opinion of publishing and not publishing physicians on improvement of producing biomedical research

\begin{tabular}{|l|c|c|c|c|}
\hline \multicolumn{1}{|c|}{ Variable } & $\begin{array}{c}\text { Publishing } \\
\text { physicians } \\
\mathbf{N = 5 4 ( \% )}\end{array}$ & $\begin{array}{c}\text { Not publishing } \\
\text { physicians } \\
\mathbf{N = 6 1}(\mathbf{\%})\end{array}$ & $\begin{array}{c}\text { Total } \\
\mathbf{N = 1 1 5} \\
\mathbf{( 1 0 0 \% )}\end{array}$ & $\begin{array}{c}\text { Significance test } \\
\text { p value }\end{array}$ \\
\hline $\begin{array}{l}\text { Unwillingness of most doctors in the } \\
\text { region to do research } \\
\text { Yes }\end{array}$ & $15(27.8)$ & $14(33.0)$ & $(25.2)$ & Chi-sq=0.35 \\
\hline
\end{tabular}




\begin{tabular}{|c|c|c|c|c|}
\hline No & $39(72.2)$ & $47(77.0)$ & $(74.8)$ & $\mathrm{P}=0.5$ \\
\hline $\begin{array}{l}\text { Reforming of undergraduate and } \\
\text { postgraduate curriculum } \\
\text { Yes } \\
\text { No }\end{array}$ & $\begin{array}{l}43(79.6) \\
11(20.4)\end{array}$ & $\begin{array}{l}43(70.5) \\
18(29.5)\end{array}$ & $\begin{array}{l}(74.8) \\
(25.2)\end{array}$ & $\begin{array}{c}\text { Chi-sq }=1.27 \\
P=0.26\end{array}$ \\
\hline $\begin{array}{l}\text { More courses about research } \\
\text { methodology } \\
\text { Yes } \\
\text { No }\end{array}$ & $\begin{array}{l}35(64.8) \\
19(35.2) \\
\end{array}$ & $\begin{array}{l}42(68.9) \\
19(31.1) \\
\end{array}$ & $\begin{array}{l}(66.9) \\
(33.1) \\
\end{array}$ & $\begin{array}{c}\text { Chi-sq }=0.2 \\
\mathrm{P}=0.6\end{array}$ \\
\hline $\begin{array}{l}\text { Awareness on importance of } \\
\text { research in clinical work } \\
\text { Yes } \\
\text { No }\end{array}$ & $\begin{array}{l}33(61.1) \\
21(38.9)\end{array}$ & $\begin{array}{l}36(59.0) \\
25(41.0)\end{array}$ & $\begin{array}{l}(60.0) \\
(40.0)\end{array}$ & $\begin{array}{c}\text { Chi-sq }=0.05 \\
\mathrm{P}=0.8\end{array}$ \\
\hline $\begin{array}{l}\text { More economic support for research } \\
\text { Yes } \\
\text { No }\end{array}$ & $\begin{array}{l}41(75.9) \\
13(24.1)\end{array}$ & $\begin{array}{l}35(57.4) \\
26(42.6)\end{array}$ & $\begin{array}{l}(66.1) \\
(33.9)\end{array}$ & $\begin{array}{l}\text { Chi-sq=4.4 } \\
\mathrm{P}=0.036^{*}\end{array}$ \\
\hline $\begin{array}{l}\text { Specify time during work for } \\
\text { research } \\
\text { Yes } \\
\text { No }\end{array}$ & $\begin{array}{l}38(70.4) \\
16(29.6) \\
\end{array}$ & $\begin{array}{l}34(55.7) \\
27(44.3) \\
\end{array}$ & $\begin{array}{l}(62.6) \\
(37.4) \\
\end{array}$ & $\begin{array}{c}\text { Chi-sq }=2.6 \\
\mathrm{P}=0.1\end{array}$ \\
\hline $\begin{array}{l}\text { Encouragement and promotion of } \\
\text { research } \\
\text { Yes } \\
\text { No }\end{array}$ & $\begin{array}{l}35(64.8) \\
19(35.2) \\
\end{array}$ & $\begin{array}{l}25(41.0) \\
36(59.0) \\
\end{array}$ & $\begin{array}{l}(52.2) \\
(47.8)\end{array}$ & $\begin{array}{c}\text { Chi-sq }=6.5 \\
\mathrm{P}=0.01^{*}\end{array}$ \\
\hline
\end{tabular}

*significant

Table 5 shows the most important variables contributing to publishing such as being a male physician, being older, having attended a research course, social commitment. In addition, political and institutional factors "decision

Table5. Logistic Regression of Variables Contributing to Publishing / Not Publishing Research

\begin{tabular}{|l|c|c|c|c|c|}
\hline & $\begin{array}{c}\boldsymbol{\beta} \\
\text { coefficient }\end{array}$ & Wald & p-value & OR & $\begin{array}{c}\text { 95\% confidence } \\
\text { interval }\end{array}$ \\
\hline Gender & 1.2 & 5.07 & 0.02 & 0.3 & $0.1-0.8$ \\
\hline Age & 0.07 & 7.6 & 0.00 & 0.9 & $0.9-1.0$ \\
\hline $\begin{array}{l}\text { Research course } \\
\text { attended }\end{array}$ & 1.3 & 7.4 & 0.00 & 3.8 & $1.4-9.8$ \\
\hline $\begin{array}{l}\text { Institution doesn't } \\
\text { give time for } \\
\text { research }\end{array}$ & 0.6 & 1.9 & 0.1 & 0.5 & $0.2-1.3$ \\
\hline $\begin{array}{l}\text { No supervisor for } \\
\text { research }\end{array}$ & 0.6 & 2.1 & 0.1 & 0.5 & $0.2-1.2$ \\
\hline $\begin{array}{l}\text { Decision makers are } \\
\text { not interested in } \\
\text { research }\end{array}$ & 0.6 & 1.3 & 0.2 & 1.9 & $0.6-5.7$ \\
\hline Social commitment & & & & & \\
\hline Constant & 2.2 & 5.5 & 0.02 & 0.1 & \\
\hline
\end{tabular}

\section{DISCUSSION}

Research contributes to the knowledge, culture and development of the society and solves its problems. Biomedical research has an impact on the health and clinical outcome [8]. Factors behind lagging of Arab countries physicians in producing biomedical publication are diverse on national, institutional as well as on personal level. An important factor mentioned by makers are not interested in research", "no time allocation for research", or "no mentor for research" affect publication. Characteristics of physician and personal factors affect publishing more than policy / institutional factors. physicians for impeding publishing was "decision makers do not consider research important". The political commitment to research and development may exist in the Arab world but does not reflect in the gross domestic expenditure on it, as World Bank data reflect that $0.04-0.7 \%$ in 2014 is spent from different Arab nations compared to the total World of over $2.08 \%$ [9]. 


\section{FACTORS RELATED TO CHARACTERISTICS of Physicians}

Female physicians in this study publish significantly less than male physician. This is worldwide the situation, where less than $30 \%$ are women authors and over $70 \%$ are men authors in science domains. Is it due to disparity in hiring, earning, funding of research $[10,11]$ or due to their smaller numbers or to their triple roles being in addition housewives and mothers? Qualitative studies on this issue are needed as studies found are bibliometric [12]. However, authors' names are not always indicating their gender, as there is no standardized way for writing the authors' name. Some names are common for both genders. Foreign names are sometimes difficult to reveal their gender.

Physicians seem to develop their interest in research and publishing a little bit later during their career. As this study revealed, the older the physicians are and the longer the duration of graduation, the higher the probability of publishing. Assumingly young physicians want to gain experience first in practicing medicine. On personal level lack of time for research seem to be an important factor.

\section{AtTendance of Research Methods COURSE}

One of the most important factors for publishing is the attendance of research methods course initiating the interest of physician in research and publishing. Probably there is recognition that these courses are enhancing research as Kuwait University initiated an extracurricular research method course for senior medical students [13] and Faculty of Medicine for Girls Al Azhar University did it for young staff members [14].

Physicians with postgraduate studies in North America are apparently more trained in research and publishing than those studying in other countries.

\section{InSTITUTIONAL FACTORS}

Institutions who built a culture of research have to develop their policy and strategy to improve research activities. It includes productive environment for research, training, funding, mentoring and continuing education [15]. In this study physicians identified institutional factors such as "no time allocated for research at work", "lack of economic support for research" and "lack of mentoring of research" contributes most to lag of research and publishing.

\section{SUGGESTIONS FOR IMPROVEMENT OF RESEARCH}

Medical education is changing all over the world since last century $[16,17]$. The majority of physicians suggest the reform of the under graduate and postgraduate curricula and research method courses which is in process in most Arab countries. In addition Jenkins and Healey suggest the integration of research in teaching [18]. The physicians propose funding of research and assigning time for it during work which is also pointed to in the Hanover Research (15).

\section{CONCLUSION}

Older male physicians publish more biomedical research than younger and females. Lack of time is an important hindering factor. Having attended a research method course encourages undertaking research and publication. Lack of institutional and policy supports such as no funds, mentoring, time and data base are limiting factors. Most physicians suggest the reform of under and postgraduate medical education.

\section{RECOMMENDATIONS}

There are different levels to encourage research: governmental, schools, university, institutions or hospitals in this case. The government has to acknowledge, that without encouraging research in general, there is no real advancement. Elias Zerhouni, former $15^{\text {th }} \mathrm{NIH}$ director (between 2002 and 2008), said that "Societies have the duty of accumulating knowledge", "Research and science go to the societies which welcome them most." (personal communication).

According to our impression this might include changing the curricula at school to include scientific thinking as well teaching research methods and basic statistics. At medical schools the knowledge of scientific work and statistics needs to be increased. Workshops on how to do research should be a must in every university curricula. Finally, hospitals should work on building a culture of research. As suggested by the Hanover Research (15), a culture of research provides a supportive context in which research is uniformly expected, discussed, produced, and valued. In May 2014, the organization published an essay entitled "Building a culture of research: recommended practices."Intellectual honesty, Accurate assignment of credit, Fairness in peer review, collegiality in scientific interactions, transparency in conflicts of interest, protection of human subjects in the conduct of research, 
humane care and treatment of animals, adherence to mutual responsibility within and between research teams

\section{LIMITATION OF THE STUDY}

Since this study was done in a conference of cardiology not all specializations were present. Only two third of attendee returned their questionnaires the reasons are not known why the other third did not participate in this study. It is possible that the percentage of publishing attendees is higher than other physicians who are not interested to attend conferences.

\section{REFERENCES}

[1] Tadmouri GO and TadmouriNB. Biomedical research in the Kingdom of Saudi Arabia (1982-2000). Saudi Med J, 2002.23(1): p. 20-4.

[2] BenamerHTS and Bakoush O. Arab nations lagging behind other Middle Eastern countries in biomedical research: a comparative study, BMC Medical Research Methodology, Bio Med Central, 2009,9: p. 26.

[3] LatifR.Medical and biomedical research productivity from the Kingdom of Saudi Arabia (2008-2012)J Family Community Med. 2015 Jan-Apr;22(1):25-30. (doi: 10.4103/22308229.149583).

[4] Bredan A, BenamerHTS and Bakoush O. Editorial, Visibility of Arab countries in the world biomedical literature, Libyan $\mathrm{J}$ Med 2011,6: 6325 -(DOI: 10.3402/ljm.v6i0.6325).

[5] UNESCO (2005) Towards Knowledge Societies - (ISBN 92- 3- 104000-6).

[6] Deleu D, Northway MG, and HanssensY. Geographical distribution of biomedical publications from the Gulf Corporation Council countries. Saudi Med J, 2001.22(1): p. 10-12.

[7] Shaban SF and Abu-ZidanFM. A quantitative analysis of medical publications from Arab countries. Saudi Med J, 2003.24(3): p. 294-6.

[8] Georghiou L. Value of research - Policy paper by the Research, Innovation and Science Policy Experts, European Commission, June 2015 (EU $27367 \mathrm{EN})$.
[9] http://data.worldbank.org/indicator/GB.XPD.R SDV.GD.ZS?locations=1A (accessed May10, 2017).

[10] LarivièreV, NiCh, Gingras $\mathrm{Y}$, Cronin Band Sugimoto CR. Bibliometrics: Global gender disparities in science COMMENT,NATURE, 11 Dec 2013.

[11] Duch J, Zeng XHT, Sales-Pardo M, Radicchi F, Otis S, Woodruff TK, et al. (2012) The Possible Role of Resource Requirements and Academic Career-Choice Risk on Gender Differences in Publication Rate and Impact. PLoS ONE 7(12): e51332. (doi:10.1371/journal.pone.0051332).

[12] Zyoud SH, Al-Jabi SW, Sweileh WM.Scientific publications from Arab world in leading journals of Integrative and Complementary Medicine: a bibliometric analysis.BMC Complement Altern Med. 2015 Sep 4; 15:308. (doi: 10.1186/s12906-015-0840-z).

[13] Al-Halabi B, Marwan Y, Hasan M, Alkhadhari S. Extracurricular research activities among senior medical students in Kuwait: experiences, attitudes, and barriers. Adv Med EducPract 2014; 5:95-101.

[14] Galal SB with a team of the Community and Industrial Medicine Department Faculty of Medicine (Girls) initiated a serial of research methodology workshops from 2006 to date. In addition the Community and Industrial Medicine Department included research methods in their undergraduate curriculum.

[15] Hanover Research, Building a culture of research: recommended practices, May 2014.

[16] Lawley TJ, Saxton JF, and JohnsMM E. Medical Education: time for reform, Trans Am ClinClimatol Assoc, 2005; 116: 311-320.

[17] Lam, Tai Pong, Bess Lam, Yu Ying. Medical education reform: the Asian experience. Academic Medicine, Vol 84(9), Sept 2009, pp 1313-1317.

[18] Jenkins A and HealeyM. Institutional strategies to link teaching and research, 2005.

Citation: Milad El-Segaier, Salma B Galal, Ahmad Bahnassy, Amin Bredan, Mohammed Omar Galal. Opinion of Arab Physicians on Factors Enhancing or Disabling their Publishing Biomedical Research. ARC Journal of Clinical Case Reports. 2017; 3(4):1-7. doi:dx.doi.org/10.20431/2455-9806.0304001.

Copyright: () 2017 Authors. This is an open-access article distributed under the terms of the Creative Commons Attribution License, which permits unrestricted use, distribution, and reproduction in any medium, provided the original author and source are credited. 